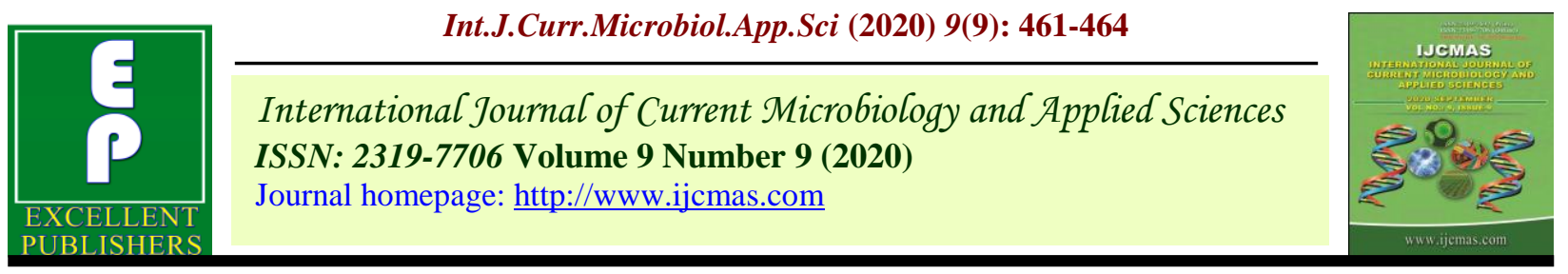

\title{
Influence of Crop Geometry and Intercropping on Growth Characters and Light Interception in Pearlmillet [Pennisetum glaucum (L.)]
}

\author{
K. Nagarajan ${ }^{1 *}$, S. Sanbagavalli ${ }^{1}$, C. Jayanthi ${ }^{1}$, Ga. Dheebakaran ${ }^{2}$ and A. Senthil ${ }^{3}$ \\ ${ }^{1}$ Department of Agronomy, Tamil Nadu Agricultural University, ${ }^{2}$ Agro Climate Research \\ Centre, ${ }^{3}$ Department of Crop Physiology, Tamil Nadu Agricultural University, Coimbatore, \\ Tamil Nadu, India \\ *Corresponding author
}

\begin{tabular}{|c|c|}
\hline & A B S T R A C T \\
\hline $\begin{array}{l}\text { Pearlmillet } \\
\text { [Pennisetum } \\
\text { glaucum }(\text { L.)] }\end{array}$ & \multirow{3}{*}{$\begin{array}{l}\text { The field experiment was conducted in Eastern Block farm, Department of Agronomy, } \\
\text { Tamil Nadu Agricultural University, Coimbatore during Kharif season (July-October) of } \\
2019 \text {. The experiment was designed in split plot design and replicated thrice. In main plots } \\
\text { viz., crop geometry [ } \mathrm{M}_{1} \text {-Pearlmillet in } 45 \times 15 \mathrm{~cm}, \mathrm{M}_{2} \text {-Pearlmillet in } 60 \times 15 \mathrm{~cm}, \mathrm{M}_{3-} \\
\text { Pearlmillet in paired row sowing } 30 / 60 \times 15 \mathrm{~cm} \text { and } \mathrm{M}_{4} \text {-Pearlmillet in paired row sowing } \\
30 / 90 \times 15 \mathrm{~cm} \text { ] and intercropping [ } \mathrm{S}_{1} \text {-Greengram, } \mathrm{S}_{2} \text {-Sesame and } \mathrm{S}_{3} \text {-No intercrop] were } \\
\text { allotted in subplots. Statistically there was no significant influence by crop geometry and } \\
\text { intercropping on plant height. Crop geometry influence the number Higher LI was found } \\
\text { in } \mathrm{M}_{1}(45 \mathrm{~cm} \times 15 \mathrm{~cm}) \text { at all the stages of crop and lower LI was observed in } \mathrm{M}_{4} \\
\text { (Pearlmillet in paired row sowing } 30 / 90 \times 15 \mathrm{~cm} \text { ). From the above results main crop as } \\
\text { well as intercrop may grow well in paired row sowing } 30 / 90 \text { x } 15 \mathrm{~cm} \text { because the } \\
\text { intercrops receive more solar radiation. }\end{array}$} \\
\hline Article Info & \\
\hline $\begin{array}{l}\text { Accepted: } \\
\text { 07 August } 2020 \\
\text { Available Online: } \\
\text { 10 September } 2020\end{array}$ & \\
\hline
\end{tabular}

\section{Introduction}

Pearl millet is an important coarse grain cereal generally grown as rainfed crop on marginal lands under low input management condition. It is adapted to drought and poor soil fertility, but responds well to good management and higher fertility levels. It is a dual-purpose crop; its grain is used for human consumption and its stalk for cattle. Crop geometry refers to the shape of space available for individual plants. Crop geometry is altered by changing inter and intra row spacing. Optimum crop geometry is one of the important factors for higher productivity by efficient utilization of resources and also harvesting as much as solar radiation for better photosynthate formation.

Limited availability of land resources and declining soil fertility both globally and as well locally, heightened the concerns regarding agriculture's ability to sustain the demands of ever-increasing population. To increase and sustain agriculture productivity we have to look for the ways of using available land and resources more effectively than in the past. This objective can be achieved by intercropping, which is an effective practice to augment the total 
productivity per unit area of the land per unit time by growing more than one crop in the same field by altering the crop geometry.

\section{Materials and Methods}

The field experiment was conducted in field No. 37F at Eastern Block farm, Department of Agronomy, Tamil Nadu Agricultural University, Coimbatore during Kharif season (July-October) of 2019. The farm is located in the Western Agro Climatic Zone of Tamil $\mathrm{Nadu}$ at 11.01701 N latitude, $76.93504 \mathrm{E}$ longitude and at an altitude of $438 \mathrm{~m}$ above MSL The experimental plot was slightly alkaline in nature with low soluble salts and a medium range of organic carbon content. The water source used for irrigation was slightly alkaline $(\mathrm{pH} 8)$ with high soluble salts (EC $5.7 \mathrm{dS} \mathrm{m}^{-1}$ ).

The experiment was designed in split plot design and replicated thrice. In main plots viz., crop geometry [ $\mathrm{M}_{1}$-Pearlmillet in $45 \times 15$ $\mathrm{cm}, \mathrm{M}_{2}$-Pearlmillet in $60 \mathrm{x} 15 \mathrm{~cm}, \mathrm{M}_{3-}$ Pearlmillet in paired row sowing 30/60 X 15 $\mathrm{cm}$ and $\mathrm{M}_{4}$-Pearlmillet in paired row sowing $30 / 90 \times 15 \mathrm{~cm}]$ and intercropping $\left[\mathrm{S}_{1}\right.$ Greengram, $\mathrm{S}_{2}$-Sesame and $\mathrm{S}_{3}$-No intercrop] were allotted in subplots. Pearlmillet (CO 10) was used as maincrop and the intercrops are greengram (CO $(\mathrm{Gg}) 8$ ) and sesame (TMV 7). Five plants were selected randomly from the net plot area of each plot for observing growth parameters.

The photosynthetically active radiation (PAR) was measured above the canopy $\left(I_{0}\right)$ and below the canopy $\left(I_{b}\right)$ adjacent to the soil surface by using AccuPAR ceptometer (Model LP-80). The measured PAR value was showed in micro mols per meter per second $\left(\mu \mathrm{mol} \mathrm{m} \mathrm{s}^{-1}\right)$. The light interception (LI) was calculated by the following equation. It is expressed in percentage.
$\mathrm{LI}=\left(1-\frac{I_{b}}{I_{0}}\right) \times 100$

Where,

LI - Light Interception

$I_{0}-$ PAR measured at above canopy, and

$I_{b}-$ PAR measured at below canopy.

\section{Results and Discussion}

\section{Effect of crop geometry and intercropping on plant height and number of tillers}

Plant hight was recorded at 30, 60 DAS and at harvest stage (Table 1). Statistically there was no significant influence by crop geometry and intercropping on plant height but numerically at 30 DAS, $\mathrm{M}_{4}$-Pearlmillet in paired row sowing 30/90 x $15 \mathrm{~cm}$ recorded maximum height $(83.6 \mathrm{~cm}) \mathrm{M}_{2}$-Pearlmillet in $60 \times 15 \mathrm{~cm}$ recorded highest plant height $(217.7 \mathrm{~cm})$ at 60 DAS, At harvesting stage $\mathrm{M}_{1}$-Pearlmillet in $45 \times 15 \mathrm{~cm}$ produced maximum height $(225.6$ $\mathrm{cm})$.with respect to intercropping there was no significant influence. Similar results were recorded by Yadav et al., (2019).

Similarly, number of tillershill ${ }^{-1}$ was recorded at various growth stages (Table 2). The tiller production was decreased as the crop reached the stage of harvest. Tiller production is significantly influenced by crop geometry on all the stages of crop. $\mathrm{M}_{4}$-Pearlmillet in paired row sowing $30 / 90 \times 15 \mathrm{~cm}$ recorded maximum number of tillers per hill at all the stages.

With respect to intercropping 30 DAS and harvesting stage there is no significant difference but at 60 DAS there was a significant difference. Higher number of tillers hill ${ }^{-1}$ was recorded in $\mathrm{S}_{3}$-no intercrop condition than the intercropping system. These results are similar to Baldevram et al., (2005). 
Table.1 Plant height as influenced by crop geometry and intercropping at various growth stages and at harvest in pearlmillet

\begin{tabular}{|c|c|c|c|c|c|c|c|c|c|c|c|c|c|c|c|}
\hline \multirow[t]{2}{*}{ Treatment } & \multicolumn{5}{|c|}{30 DAS } & \multicolumn{5}{|c|}{60 DAS } & \multicolumn{5}{|c|}{ At harvest } \\
\hline & $\mathbf{M}_{1}$ & $\mathbf{M}_{2}$ & $\mathbf{M}_{3}$ & $\mathbf{M}_{4}$ & Mean & $\mathbf{M}_{1}$ & $\mathbf{M}_{2}$ & $\mathbf{M}_{3}$ & $\mathbf{M}_{4}$ & Mean & $\mathbf{M}_{1}$ & $\mathbf{M}_{2}$ & $\mathbf{M}_{3}$ & $\mathbf{M}_{4}$ & Mean \\
\hline $\mathbf{S}_{1}$ & 81.1 & 79.9 & 80.5 & 80.2 & 80.4 & 224.1 & 218.2 & 187.7 & 202.7 & 208.1 & 227.0 & 225.5 & 199.2 & 210.9 & 215.6 \\
\hline $\mathbf{S}_{2}$ & 82.3 & 78.8 & 82.7 & 83.2 & 81.8 & 220.0 & 205.1 & 202.2 & 208.2 & 208.9 & 230.5 & 211.8 & 206.6 & 214.4 & 215.8 \\
\hline $\mathbf{S}_{\mathbf{3}}$ & 77.9 & 81.9 & 77.3 & 87.3 & 81.1 & 203.4 & 230.0 & 213.7 & 197.2 & 211.1 & 219.4 & 231.1 & 221.1 & 207.7 & 219.8 \\
\hline Mean & 80.4 & 80.2 & 80.2 & 83.6 & 81.1 & 215.8 & 217.7 & 201.2 & 202.7 & 209.4 & 225.6 & 222.8 & 209.0 & 211.0 & 217.1 \\
\hline
\end{tabular}

\begin{tabular}{|l|l|l|l|l|l|l|l|l|l|l|l|l|}
\hline & M & S & M at S & S at M & M & S & M at S & S at M & M & S & M at S & S at M \\
\hline SEd & 4.3 & 2.5 & 5.8 & 4.9 & 8.3 & 7.0 & 14.1 & 13.9 & 8.9 & 5.7 & 12.9 & 11.4 \\
\hline $\mathbf{C D}(\mathbf{P}=\mathbf{0 . 0 5})$ & NS & NS & NS & NS & NS & NS & NS & NS & NS & NS & NS & NS \\
\hline
\end{tabular}

Table.2 Numbers of tillers per hill as influenced by crop geometry and intercropping at various growth stages and at harvest in pearlmillet

\begin{tabular}{|c|c|c|c|c|c|c|c|c|c|c|c|c|c|c|c|}
\hline \multirow[t]{2}{*}{ Treatment } & \multicolumn{5}{|c|}{30 DAS } & \multicolumn{5}{|c|}{60 DAS } & \multicolumn{5}{|c|}{ At harvest } \\
\hline & $\mathbf{M}_{1}$ & $\mathbf{M}_{2}$ & $\mathbf{M}_{3}$ & $\mathbf{M}_{4}$ & Mean & $\mathbf{M}_{1}$ & $\mathbf{M}_{2}$ & $\mathbf{M}_{3}$ & $\mathbf{M}_{4}$ & Mean & $\mathbf{M}_{1}$ & $\mathbf{M}_{2}$ & $\mathbf{M}_{3}$ & $\mathbf{M}_{4}$ & Mean \\
\hline $\mathbf{S}_{1}$ & 5.0 & 5.2 & 5.2 & 6.5 & 5.5 & 3.1 & 4.0 & 3.1 & 4.1 & 3.6 & 2.1 & 2.1 & 2.4 & 2.7 & 2.3 \\
\hline $\mathbf{S}_{2}$ & 6.0 & 5.2 & 4.8 & 5.5 & 5.4 & 3.3 & 4.1 & 4.0 & 3.7 & 3.8 & 1.8 & 2.5 & 2.3 & 2.7 & 2.3 \\
\hline $\mathbf{S}_{\mathbf{3}}$ & 4.9 & 5.9 & 5.3 & 6.4 & 5.6 & 3.6 & 4.1 & 4.1 & 4.8 & 4.2 & 2.4 & 2.2 & 2.2 & 2.9 & 2.4 \\
\hline Mean & 5.3 & 5.4 & 5.1 & 6.1 & 5.5 & 3.3 & 4.0 & 3.8 & 4.2 & 3.8 & 2.1 & 2.2 & 2.3 & 2.8 & 2.4 \\
\hline
\end{tabular}

\begin{tabular}{|l|l|l|l|l|l|l|l|l|l|l|l|l|}
\hline & $\mathbf{M}$ & $\mathbf{S}$ & $\mathbf{M}$ at S & $\mathbf{S}$ at M & $\mathbf{M}$ & $\mathbf{S}$ & $\mathbf{M}$ at S & $\mathbf{S}$ at M & $\mathbf{M}$ & $\mathbf{S}$ & $\mathbf{M}$ at S & $\mathbf{S}$ at M \\
\hline SEd & 0.22 & 0.17 & 0.36 & 0.35 & 0.13 & 0.12 & 0.23 & 0.24 & 0.10 & 0.07 & 0.15 & 0.15 \\
\hline $\mathbf{C D}(\mathbf{P}=\mathbf{0 . 0 5})$ & 0.53 & NS & 0.80 & 0.73 & 0.31 & 0.25 & 0.51 & 0.50 & 0.24 & NS & 0.35 & 0.31 \\
\hline
\end{tabular}

Table.3 Effect of crop geometry and intercropping on light interception at various growth stages $(\%)$

\begin{tabular}{|c|c|c|c|c|c|c|c|c|c|c|c|c|c|c|c|}
\hline & \multicolumn{5}{|c|}{30 DAS } & \multicolumn{5}{|c|}{60 DAS } & \multicolumn{5}{|c|}{ At harvest } \\
\hline & $\mathbf{M}_{1}$ & $\mathbf{M}_{2}$ & $\mathbf{M}_{3}$ & $\mathbf{M}_{4}$ & Mean & $\mathbf{M}_{1}$ & $\mathbf{M}_{2}$ & $\mathbf{M}_{3}$ & $\mathbf{M}_{4}$ & Mean & $\mathbf{M}_{1}$ & $\mathbf{M}_{2}$ & $\mathbf{M}_{3}$ & $\mathbf{M}_{4}$ & Mean \\
\hline $\mathbf{S}_{1}$ & 80.3 & 73.3 & 66.6 & 67.1 & 71.8 & 92.8 & 88.5 & 89.2 & 82.3 & 88.2 & 75.9 & 70.2 & 70.2 & 38.1 & 63.6 \\
\hline $\mathbf{S}_{2}$ & 79.0 & 72.2 & 74.2 & 65.9 & 72.8 & 89.7 & 88.2 & 82.5 & 70.6 & 82.8 & 75.5 & 67.4 & 74.1 & 40.6 & 64.4 \\
\hline $\mathbf{S}_{\mathbf{3}}$ & 75.5 & 71.2 & 73.0 & 66.6 & 71.6 & 89.9 & 89.6 & 78.3 & 75.7 & 83.4 & 75.3 & 69.5 & 69.4 & 45.3 & 64.9 \\
\hline \multirow[t]{2}{*}{ Mean } & 78.2 & 72.2 & 71.3 & 66.5 & 72.1 & 90.8 & 88.8 & 83.4 & 76.2 & 84.8 & 75.5 & 69.0 & 71.2 & 41.3 & 64.3 \\
\hline & & $\mathbf{M}$ & $\mathbf{S}$ & \multicolumn{2}{|c|}{ M at $\mathbf{S}$} & $\mathbf{M}$ & \multicolumn{2}{|c|}{$\mathbf{S}$} & \multicolumn{2}{|c|}{ M at $\mathrm{S}$} & $\mathbf{M}$ & \multicolumn{2}{|l|}{$\mathbf{S}$} & \multicolumn{2}{|c|}{ M at S } \\
\hline \multicolumn{2}{|l|}{ SEd } & 2.16 & 1.94 & \multicolumn{2}{|c|}{3.83} & 2.58 & \multicolumn{2}{|c|}{2.10} & \multicolumn{2}{|c|}{4.29} & 2.46 & \multicolumn{2}{|c|}{2.41} & \multicolumn{2}{|l|}{4.64} \\
\hline \multicolumn{2}{|c|}{$\mathrm{CD}(\mathrm{P}=0.05)$} & 5.29 & NS & \multicolumn{2}{|c|}{ NS } & 6.32 & \multicolumn{2}{|c|}{4.44} & \multicolumn{2}{|l|}{ NS } & 6.0 & \multicolumn{2}{|c|}{ NS } & \multicolumn{2}{|l|}{ NS } \\
\hline
\end{tabular}




\section{Effect of crop geometry and intercropping on light interception}

Light Interception (\%) was significantly influenced due to difference in interrow spacing of pearlmillet. Higher LI was found in $M_{1}(45 \mathrm{~cm} \mathrm{X} 15 \mathrm{~cm})$ at all the stages of crop and lower LI was observed in $\mathrm{M}_{4}$ (Pearlmillet in paired row sowing 30/90 x $15 \mathrm{~cm}$ ) (Table $3)$. Narrow spacing crop covers the soil better than other crop geometry which was reason for better LI, similar result was obtained by Mohan Kumar et al., (2019) and Steiner (1986). Sub plots shows significant in LI due to growth behaviour of intercrops. Intercropping with greengram $\left(\mathrm{S}_{1}\right)$ shows significantly higher LI $(88 \%)$ at 60 DAS. Yogesh et al., (2014) et al., (2014) found similar results in maize with soybean (1:1) inter cropping system.

It is concluded that plant height not influenced by crop geometry and intercropping. Pearlmillet in paired row sowing 30/90 x $15 \mathrm{~cm}$ a greater number of tillers. Sole pearl millet recorded more plant height and tillers hill ${ }^{-1}$. Light interception was low in Pearlmillet in paired row sowing 30/90 $x 15 \mathrm{~cm}$. From the above results main crop as well as intercrop may grow well in paired row sowing 30/90 x $15 \mathrm{~cm}$ because the intercrops receive more solar radiation. Since the findings are based on the research done in one season it may be repeated for further confirmation.

\section{References}

Baldevram, Choudhary, G.R., Jat, A.S and Jat, M.L. 2005. Effect of integrated weed management and intercropping systems on growth and yield of pearlmillet (Pennisetum glaucum). Indian Journal of Agronomy. 50 (3): 210 - 213.

Mohan Kumar, S., N. Thavaprakaash, S. Paneerselvam, R. Jagadeeswaran, and N. Sritharan. 2019. "Effect of high density planting on light interception, growth and yield of rice (Oryza sativa L.) under modified system of rice intensification." International Journal of Agriculture Sciences, 11 (12): 0975-3710.

Steiner, JL. 1986. "Dryland Grain Sorghum Water Use, Light Interception, and Growth Responses to Planting Geometry 1." Agronomy Journal 78 (4):720-726.

Yadav, B. L., B. S. Patel, Shaukat Ali, and S. K. Yadav. 2019. "Intercropping of legumes and oil seed crop in summer pearlmillet [Pennisetum glaucum (L.) " Legume Research-An International Journal 71 (1979): 252-253. doi: 10.5958/0976-0571.2015.00068.5.

Yogesh, S, SI Halikatti, SM Hiremath, MP Potdar, SI Harlapur, and H Venkatesh. 2014. "Light use efficiency, productivity and profitability of maize and soybean intercropping as influenced by planting geometry and row proportion." Karnataka Journal of Agricultural Sciences 27 (1):1-4.

\section{How to cite this article:}

Nagarajan, K., S. Sanbagavalli, C. Jayanthi, Ga. Dheebakaran and Senthil, A. 2020. Influence of Crop Geometry and Intercropping on Growth Characters and Light Interception in Pearlmillet [Pennisetum glaucum (L.)]. Int.J.Curr.Microbiol.App.Sci. 9(09): 461-464. doi: https://doi.org/10.20546/ijcmas.2020.909.058 